\title{
Mediasi Penal Sebagai Bentuk Penanganan Perkara Anak
}

\author{
Penal Mediation as a Form of Handling Child Cases
}

\author{
Fitrayadi \\ Kasat Reskrim Polres Konawe Selatan \\ E-mail: fitrayadi1340@gmail.com \\ Oheo K. Haris \\ Pascasarjana Universitas Halu Oleo \\ E-mail: oheo.haris@uho.ac.id \\ Handrawan \\ Pascasarjana Universitas Halu Oleo \\ E-mail: handrawansaranani84@gmail.com
}

\begin{abstract}
This Research is aimed at solving child criminal cases through Penal mediation, as a form of diversion (diversion) in the settlement of juvenile criminal cases in Indonesia, can be seen from the ideas and working principles of penal mediation, which are very suitable for the purpose of diversion (transfer) of juvenile cases from the criminal justice process. Second, penal mediation as a form of solving juvenile criminal cases, is in line with the approach using restorative justice. Restorative justice which seeks to shift the paradigm so far that the settlement of criminal cases must be punished, in accordance with the ideas and working principles of penal mediation which prioritizes deliberation. Third; the process of dispute resolution by means of mediation, whether carried out within the criminal justice system or outside the court, namely the existence of an agreement or peace agreement which has both evidentiary value and is binding for the parties. However, both of them do not yet have definite legal force as befits a court decision that has permanent legal force. A peace agreement resulting from mediation in court can be immediately upgraded to a peace deed through a panel of judges examining the case at the time of trial and decided to become a court decision. Meanwhile, a peace agreement or agreement resulting from out-of-court mediation will only obtain a position as a peace deed after the parties with the help of the mediator file a peace suit through the District Court, vide. Article 36 PERMA Number 1 of 2016. Thus, the peace deed has legal certainty and has permanent legal force (incracht van gewijsde).
\end{abstract}

Keywords: Penal Mediation; Diversion; Restorative Justice 


\begin{abstract}
Abstrak: Penelitian ini ditujukan untuk menyelesaikan perkara pidana anak melalui mediasi penal sebagai bentuk diversi (pengalihan) dalam penyelesaian perkara pidana anak di Indonesia, dapat terlihat dari ide dan prinsip kerja mediasi penal, yang sangat sesuai dengan tujuan diversi (pengalihan) perkara anak dari proses peradilan pidana. Kedua, mediasi penal sebagai bentuk penyelesaian perkara pidana pidana anak, sejalan dengan pendekatan menggunakan keadilan restoratif. Restorative justice yang berupaya menggeser paradigma selama ini bahwa penyelesaian perkara pidana harus dengan pemidanaan, sesuai dengan ide dan prinsip kerja mediasi penal yang lebih mengutamakan musyawarah. Ketiga; proses penyelesaian sengketa dengan cara mediasi, baik yang dilaksanakan di dalam sistem peradilan pidana maupun di luar pengadilan, yaitu adanya kesepakatan atau perjanjian perdamaian yang sama-sama memiliki nilai pembuktian dan mengikat bagi para pihak. Namun, keduanya belum memiliki kekuatan hukum yang pasti sebagaimana layaknya putusan pengadilan yang berkekuatan hukum tetap. Kesepakatan perdamaian hasil dari mediasi di dalam pengadilan dapat langsung ditingkatkan statusnya menjadi akta perdamaian melalui majelis hakim pemeriksa perkara pada saat persidangan dan diputus menjadi putusan pengadilan. Sedangkan, perjanjian atau kesepakatan perdamaian hasil mediasi di luar pengadilan, baru memperoleh kedudukan sebagai akta perdamaian setelah para pihak dengan bantuan mediator mengajukan gugatan perdamaian melalui Pengadilan Negeri, vide. Pasal 36 PERMA Nomor 1 Tahun 2016. Sehingga, akta perdamaian dimaksud memiliki kepastian hukum dan berkekuatan hukum tetap (incracht van gewijsde).
\end{abstract}

Kata kunci: Mediasi Penal; Diversi; Keadilan Restoratif

\title{
PENDAHULUAN
}

Mediasi penal merupakan alternatif penyelesaian perkara pidana di luar jalur penal. Dalam penyelesaian perkara pidana jika menempuh jalur penal biasanya selalu adanya penjatuhan pidana oleh hakim terhadap pelaku, hal ini secara filosofis kadang-kadang tidak memuaskan semua pihak, oleh karena itu perlu adanya pemikiran penyelesaian perkara pidana melalui jalur ADR (Alternative Dispute Resolution) dengan maksud agar dapat menyelesaikan konflik yang terjadi antara pelaku dengan korban. Pendekatan melalui jalur ADR, pada mulanya termasuk dalam wilayah hukum keperdataan, namun dalam perkembangannya dapat pula digunakan oleh hukum pidana, hal ini sebagaimana diatur dalam dokumen penunjang Kongres PBB ke-6 Tahun 1995 dalam Dokumen A/CO NF. 169/6 menjelaskan dalam perkara-perkara pidana yang mengandung unsur fraud dan white-collar crime atau apabila terdakwanya korporasi, maka pengadilan seharusnya tidak menjatuhkan pidana, tetapi mencapai suatu hasil yang bermanfaat bagi kepentingan masyarakat secara menyeluruh dan mengurangi kemungkinan terjadinya pengulangan. ${ }^{1}$

1 Barda Nawawi Arief, dalam Sahuri Lasmadi, "Mediasi Penal dalam Sistem Peradilan Pidana Indonesia", Jurnal Ilmu Hukum Inovatif, Vol. 4 No. 5, 2011, hlm. 2. 
Menurut Muladi, ${ }^{2}$ model konsensus yang dianggap menimbulkan konflik baru harus diganti dengan model asensus, karena dialog antara yang berselisih untuk menyelesaikan masalahnya, adalah langkah yang sangat positif. Dengan konsep ini muncul istilah ADR yang dalam hal-hal tertentu menurut Muladi lebih memenuhi tuntutan keadilan dan efisien. ADR ini merupakan bagian dari konsep restorative justice yang menempatkan peradilan pada posisi mediator. Untuk lebih jelasnya dapat dilihat dalam United Nations Office for Drug Control and Crime Prevention, dinyatakan bahwa restorative justice merupakan sebuah istilah baru terhadap konsep lama. Pendekatan restorative justice telah digunakan dalam memecahkan masalah konflik antara para pihak dan memulihkan perdamaian di masyarakat. Karena pendekatan-pendekatan retributive atau rehabilitative terhadap kejahatan dalam tahun-tahun terakhir ini dianggap sudah tidak memuaskan lagi. Oleh karenanya menyebabkan dorongan untuk beralih kepada pendekatan restorative justice. Kerangka pendekatan restorative justice melibatkan pelaku, korban dan masyarakat dalam upaya untuk menciptakan keseimbangan, antara pelaku dan korban. Juga dapat dilihat dalam Dokumen A/CONF. 187/8 yang disampaikan pada kongres PBB ke-10 Tentang The Prevention of Crime and the Treatment of Offenders yang diselenggarakan di Vienna, 1017 April 2000, yang mana pada bagian Basic Principles of Justice for Offenders and Victims, antara lain dicantumkan mengenai the Alternative of Restorative Justice. ${ }^{3}$

Menurut dokumen restorative justice dipandang sebagai sebuah model alternatif dalam peradilan pidana. Di mana semua pihak ambil bagian untuk menyelesaikan permasalahan tertentu secara bersama-sama bagaimana menghadapi akibat dari permasalahan itu serta implikasinya bagi yang akan datang. Dalam model ini, penekanannya terletak pada perbaikan (reparation) dan pencegahan (prevention) ketimbang menjatuhkan pidana. Restorative justice ini dan bentuk-bentuk lainnya dari penyelesaian perselisihan (dispute resolution) baik formal maupun semi formal, mencerminkan kecenderungan masa kini dari paham individualisme dan mengurangi fungsi dari negara.

Menurut Adam Graycar, ${ }^{4}$ bahwa dalam praktiknya restorative justice, memerlukan dukungan teori reintegrative shaming dalam menyelesaikan konflik. Graycar menjelaskan dengan menyitir pendapat Braithwaite mengenai teori reintegrative shaming, bahwa ada dua segi utama yang melekat pada proses restorative, yakni: (1) untuk mencapai

\footnotetext{
2 Muladi, Hak Asasi Manusia, Politik dan Sistem Peradilan Pidana, Semarang: Badan Penerbit Universitas Diponegoro, 1997, hlm.67.

3 Ibid.

4 Adam Graycar, dalam Sahuri Lasmadi, Op. cit., hlm. 3.
} 
keberhasilan reintegrasi itu, maka proses yang dilakukan harus melibatkan kehadiran dan peran serta masyarakat bagi dukungan terhadap pelaku dan korban; (2) proses yang memerlukan adanya perasaan malu (shaming) sebagai pencelaan (confrontation) atas perbuatan salah antara pelaku dan korban. Proses melalui pendekatan restoratif ini bertujuan untuk: (a) menjelaskan kepada pelaku bahwa perbuatan tersebut merupakan perbuatan yang tercela di masyarakat, (b) dukungan dan menghargai seseorang walaupun perbuatannya tersebut merupakan perbuatan yang tercela. Dengan demikian, tujuan dari program restoratif tersebut, ialah mengembalikan pelaku dan korban ke dalam masyarakat, agar mereka dapat menjadi anggota masyarakat yang bertanggung jawab, mematuhi hukum dan menjunjung tinggi nilai-nilai yang hidup dalam masyarakat. Dengan pemikiran tersebut di atas perlu adanya pemikiran untuk menyelesaikan perkara pidana melalui jalur mediasi penal sebagai upaya untuk menyelesaikan konflik yang terjadi secara menyeluruh sehingga para pihak yang berperkara dapat menyelesaikan masalah dengan kesadaran sendiri dengan mengutamakan saling pengertian dan penghormatan kepada hak-hak korban.

Di Indonesia melalui Undang-Undang Nomor 11 Tahun 2012 Tentang Sistem Peradilan Pidana Anak, penyelesaian perkara pidana anak, dimungkinkan diselesaikan dengan upaya diversi (pengalihan). Artinya, bahwa penyelesaian perkara pidana anak berusaha dialihkan ke luar jalur peradilan pidana formal menuju peradilan non formal. Salah satu bentuk alternatif penyelesaian perkara melalui jalur peradilan non formal, yakni "mediasi penal". Mediasi penal berarti penyelesaian perkara pidana melalui musyawarah dengan bantuan mediator yang netral, dihadiri korban dan pelaku serta perwakilan masyarakat, dengan tujuan pemulihan bagi korban, pelaku dan lingkungan masyarakat. Melihat kesamaan antara konsep mediasi penal dan diversi itu, maka tulisan ini hendak mengkaji perihal kesamaan mediasi penal dengan diversi. Sehingga kesamaan tersebut, diharapkan menjadi landasan bahwa mediasi penal dapat digunakan sebagai bentuk diversi (pengalihan) khususnya dalam menyelesaikan perkara pidana anak. Mengingat banyaknya keuntungan yang ada pada mediasi penal, sebagaimana telah dipraktikkan di beberapa negara, maka diperlukan upaya berupa kajian untuk menerapkan mediasi penal dalam proses peradilan pidana Indonesia sebagai bagian dari sistem peradilan pidana di Indonesia.

Berdasarkan uraian latar belakang maka permasalahan yang menjadi fokus dalam penelitian ini adalah apakah mediasi penal dapat diterapkan dalam sistem peradilan pidana ? Dan apakah mediasi penal dapat digunakan dalam penanganan perkara anak? 


\section{METODE PENELITIAN}

Penelitian ini menggunakan tipologi penelitian hukum normatif khususnya yang berkaitan dengan mediasi penal sebagai bentuk penanganan perkara anak. Peter Mahmud Marzuki, 5 menyatakan bahwa penelitian hukum merupakan proses untuk menemukan aturan hukum, prinsip-prinsip hukum, maupun doktrin-doktrin hukum guna menjawab isu hukum yang dihadapi. Penelitian hukum normatif dilakukan untuk menghasilkan argumentasi, teori atau konsep baru sebagai gambaran dalam menyelesaikan masalah yang dihadapi. ${ }^{6}$ Penelitian ini menekankan pada mediasi penal sebagai bentuk penanganan perkara anak.

Pendekatan-pendekatan yang digunakan di dalam penelitian hukum adalah pendekatan undang-undang (statute approach), Pendekatan konsep (Conceptual Approach) dan pendekatan kasus (case approach). Pendekatan Peraturan Perundang-undangan (Statute approach) yaitu dengan menelusuri setiap peraturan perundang-undangan yang mengatur mengenai mediasi penal dalam penanganan perkara anak. Pendekatan konseptual (Conseptual approach) yaitu gabungan antara asas hukum dan doktrin para ahli hukum pidana yang digunakan untuk memahami konsep hukum pidana terkait mediasi penal dalam penanganan perkara anak, sehingga diharapkan penormaan dalam aturan hukum dalam mengkaji serta menganalisis kerangka pikir atau kerangka konseptual maupun landasan teoritis sesuai dengan tujuan penelitian ini.

\section{ANALISIS DAN PEMBAHASAN}

\section{Penerapan Mediasi Penal dalam Sistem Peradilan Pidana}

Mediasi penal merupakan salah satu bentuk dari pelaksanaan restorative justice, yaitu konsep yang memandang kejahatan secara lebih luas. Konsep ini memandang bahwa kejahatan atau tindak pidana bukanlah hanya sekedar urusan pelaku tindak pidana dengan negara yang mewakili korban, dan meninggalkan proses penyelesaiannya hanya kepada pelaku dan negara (Jaksa penuntut umum). Restorative justice menuntut proses peradilan pidana untuk memberikan pemenuhan kepentingan-kepentingan korban sebagai pihak yang dirugikan akibat perbuatan pelaku. Sehingga diperlukan pergeseran paradigma dalam pemidanaan untuk menempatkan mediasi penal sebagai bagian dari sistem peradilan pidana.

5 Peter Mahmud Marzuki, Penelitian Hukum, Jakarta: Kencana, 2005, hlm. 35.

6 Yulianto Achmad, Mukti Fajar. Dualisme Penelitian Hukum Normatif \& Empiris, Yogyakarta: Pustaka Pelajar, 2010, hlm. 48. 


\section{Mediasi Penal Tahap Penyidikan}

Pada tahap ini dapat ditetapkan cara kerja mediasi penal sebagai berikut: ${ }^{7}$

(a) Setelah melihat dan mempelajari kasus atau tindak pidana yang dilakukan oleh pelaku dengan kriteria-kriteria tertentu (diuraikan dalam bahasan tindak pidana yang dapat dimediasikan), maka pihak penyidik memanggil pelaku dan korban untuk menawarkan alternatif penyelesaian perkara pidananya di luar proses peradilan.

(b) Mediasi penal harus dilakukan secara suka rela dari semua pihak yang terlibat. oleh karena itu jika ada pernyataan baik dari pelaku maupun korban untuk melakukan mediasi penal, selanjutnya pihak penyidik menyerahkan perkara tersebut kepada korban dengan menginformasikan jasa mediator penal yang akan membantu menyelesaikan perkaranya.

(c) Mediasi dilakukan secara rahasia sesuai dengan prinsip confidentiality. Segala yang terjadi dan pernyataan-pernyataan yang muncul selama proses mediasi harus dirahasiakan oleh semua pihak termasuk mediator. Mediator tidak dapat menjadi saksi dalam proses peradilan pidana atas segala sesuatu yang terjadi selama proses mediasi dan sebab-sebab mediasi tidak mencapai kesepakatan, jika mediasi tidak menghasilkan kesepakatan.

(d) Pada kesempatan mediasi inilah pelaku dan korban dipertemukan untuk mencari solusi yang saling menguntungkan. Pihak korban dapat mengajukan tuntutan ganti kerugian kepada pelaku sebesar kerugian yang dideritanya dan menuntut pemulihan martabatnya, dengan difasilitasi oleh mediator.

(e) Mediator harus mempunyai sertifikasi dan terlatih serta diakui oleh Menteri Kehakiman sebagai mediator, oleh karena itu mediator tidak bersifat perorangan melainkan suatu badan atau lembaga yang secara khusus menjalankan tugas mediasi.

(f) Apabila dalam mediasi dicapai kesepakatan, maka mediator memberitahukan kepada penyidik bahwa telah dicapai kesepakatan melalui mediasi dengan pembayaran ganti kerugian dari pelaku kepada korban.

(g) Hasil kesepakatan mediasi penal merupakan putusan final, sehingga merupakan alasan penghapus penuntutan.

7 Umi Rozah, "Membangun Konstruksi Politik Hukum Medias Penal Sebagai Alternatif Penyelesaian Perkara Pidana", Jurnal Masalah-masalah Hukum, Vol. 39, No. 3, 2010, hlm. 293. 
(h) Dengan adanya hasil kesepakatan maka penyidik menyatakan bahwa kasus tidak dilanjutkan kepada pelimpahan SAP kepada penuntut.

\section{Mediasi Penal pada Tahap Penuntutan}

Dalam mediasi ini pihak korban dapat meminta ganti kerugian kepada pelaku, namun demikian apabila terjadi kesepakatan dari pihak korban dan pelaku untuk mengganti kerugian, kesepakatannya tidak menghilangkan penuntutan, sehingga proses peradilan tetap berjalan sebagaimana mestinya, dan kesepakatan ganti kerugian hanya bersifat sebagai pertimbangan jaksa dalam mengadakan penuntutan, keputusan tetap di tangan hakim. Mediasi penal di sini hanya bersifat memperingan tuntutan, oleh karena belum ada undang-undang yang mengatur pelaksanaan mediasi beserta kekuatan hukum dari akta kesepakatan hasil mediasi penal. Jadi pelaku tetap dipidana akan tetapi pidananya diperingan.

Sementara itu dalam menangani kasus tindak pidana yang masuk ke dalam katagori 'delik biasa', seperti kasus-kasus yang mengandung unsur kelalaian seperti dalam Pasal 359 KUHP (karena kelalaiannya menyebabkan matinya orang lain), serta dalam tindak pidana terhadap harta benda seperti Pasal 372 KUHP tentang penggelapan, dan Pasal 378 tentang penipuan, yang biasanya antara korban dan pelaku sudah saling mengenal, maka dapat dilakukan mediasi di mana korban dapat meminta ganti kerugian kepada pelaku dengan sebuah akta kesepakatan bahwa telah dilakukan pembayaran ganti kerugian kepada korban.

Pelaksanaan mediasi penal pada tahap penuntutan dapat digambarkan sebagai berikut: 8

a. Jaksa penuntut umum dengan mempelajari tindak pidana yang dilakukan oleh pelaku berdasarkan kriteria-kriteria tertentu, dapat menawarkan mediasi kepada korban dan pelaku tindak pidana.

b. Mediasi dilakukan berdasarkan persetujuan secara suka rela dari pelaku dan korban tindak pidana. Jika kedua pihak menyetujui untuk dilakukan mediasi, maka persetujuan untuk mediasi diberikan kepada jaksa penuntut umum.

c. Jaksa penuntut umum dapat berposisi sebagai mediator maupun dapat melakukan penunjukan mediator dari luar yang bersertifikasi.

d. Mediator mempertemukan pihak pelaku dan korban tindak pidana.

$8 \quad$ Ibid., hlm. 292-293. 
e. Pelaksanaan proses mediasi dilakukan secara rahasia, dalam arti semua peristiwa yang terjadi dan pernyataan-pernyataan yang muncul selama mediasi tidak dapat dipublikasikan oleh semua pihak yang terlibat.

f. Dalam mediasi penal ini diadakan rekonsiliasi dan pembayaran ganti kerugian kepada korban.

g. Jika mediasi penal tidak mencapai kesepakatan, maka perkara pidana akan dilanjutkan dengan proses pemeriksaan di sidang pengadilan dengan dilakukan penuntutan terhadap tindak pidananya. Dalam hal ini mediator tidak dapat bersaksi atas tidak tercapainya kesepakatan mediasi maupun alas segala sesuatu yang terjadi selama proses mediasi.

h. Jika mediasi mencapai kesepakatan damai yang diterima oleh semua pihak, maka akta kesepakatan berlaku sebagai putusan yang final dan tidak dapat diadakan penuntutan, sehingga dapat berfungsi sebagai alasan penghapus penuntutan.

\section{Mediasi Penal pada Tahap Pemeriksaan Pengadilan}

Dalam hukum pidana tidak dikenal mediasi penal, namun demikian ada kesempatan bagi korban untuk menggugat ganti kerugian kepada pelaku melalui gugatan perdata dan proses peradilan pidana tetap dijalankan. Namun sebenarnya apabila kita mempermasalahkan mediasi penal dalam hal penentuan pengganti kerugian dari pelaku kepada korban hal ini dimungkinkan, yang dapat dijadikan dasar pertimbangan hakim dalam menjatuhkan pidana bersyarat. Pengganti kerugian terhadap korban dalam pidana bersyarat merupakan salah satu syarat khusus yang telah dilakukan oleh terpidana.

Di samping ketentuan pidana yang akan dijatuhkan oleh hakim tidak lebih dari 1 (satu\} tahun untuk pidana penjara. Masyarakat sebenarnya membutuhkan lembaga mediasi penal, khususnya untuk delik-delik aduan. seperti penghinaan, tindak pidana pencurian yang melibatkan anggota keluarga, kasus-kasus yang unsur pidananya tidak jelas. dan kasus-kasus dengan nilai kerugian yang ringan atau sedikit. Dalam kasus-kasus seperti ini apabila tetap diproses dalam peradilan pidana justru akan lebih banyak nilai kerugiannya. Pengalaman praktik mediasi penal oleh hakim tidak pernah dilakukan, oleh karena tidak ada peraturan normatif yang mengaturnya, biasanya hal-hal yang menyangkut kesepakatan para pelaku dan korban ada pada tingkat penyidikan dan penuntutan, hakim hanya memberikan keputusan dengan mempertimbangkan hal-hal yang dikemukakan dalam surat 
dakwaan yang salah satunya kesepakatan yang dicapai melalui mediasi sebelum perkara dilimpahkan ke pengadilan.

Temuan praktik mediasi di tingkat Mahkamah Agung RI bahwa mediasi penal di lingkungan Mahkamah Agung telah dipraktikkan dalam kasus tindak pidana yang pelakunya anak di bawah umur. Pelaksanaan mediasi penal untuk pelaku anak di bawah umur ini didasarkan pada Kesepakatan Antara Ketua Mahkamah Agung, Wakil Ketua Mahkamah Agung, dan Para Ketua Muda Mahkamah Agung dalam Rapat Pimpinan Mahkamah Agung RI di Novotel Hotel Bagor tanggal 17 Mei 2009 yang membahas tentang Temuan-temuan Hukum serta Permasalahan-permasalahan yang Timbul di Mahkamah Agung dan Jajaran Peradilan di Bawahnya. Praktik mediasi penal untuk pelaku anak di bawah umur telah diuji coba di lingkungan Pengadilan Negeri Jawa Barat.

\section{Mediasi Penal dalam Penanganan Perkara Anak \\ Penanganan Perkara Anak Dalam Bentuk Diversi}

Mediasi penal dalam penanganan konflik yang mengupayakan para pihak (penegak hukum, pelaku, korban, masyarakat) melupakan kerangka hukum formal (sistem peradilan pidana formal). Mediasi penal mendorong para pihak terlibat dalam proses komunikasi. Menangani konflik dengan komunikasi, tidak selalu harus dengan jalur pemidanaan, hal ini sangat relevan dengan konsep diversi (pengalihan). Diversi (pengalihan) yang berupaya untuk menyelesaikan perkara pidana anak dengan mengupayakan para pihak melupakan kerangka hukum formal yang ada, sangat sesuai dengan ide dan prinsip kerja mediasi penal. Dalam suatu perkara pidana yang pelakunya adalah anak, maka dalam rangka mengalihkan anak dari proses peradilan pidana formal, diupayakan komunikasi antara anak (pelaku), orang tua/wali anak, dengan korban dan masyarakat. Komunikasi ini diharapkan dapat menjadi wadah untuk mencapai titik temu dalam penyelesaian perkara pidana, sehingga perkara pidana tersebut tidak mesti dibawa pada proses peradilan pidana formal. Penanganan konflik dengan jalur komunikasi sebagai ide/ prinsip kerja mediasi penal, sangat sesuai dengan konsep diversi pada penyelesaian perkara pidana anak. Oleh sebab itu, mediasi penal dapat digunakan sebagai implementasi bentuk diversi dalam penyelesaian perkara pidana anak.

Kedua, mediasi penal yang berorientasi pada proses, yang dapat digunakan sebagai bentuk diversi. Mediasi penal lebih berorientasi pada kualitas proses daripada hasil, yaitu menyadarkan pelaku tindak pidana akan kesalahannya, kebutuhan-kebutuhan konflik 
terpecahkan, ketenangan korban dari rasa takut. Hal ini sangat relevan dengan konsep diversi (pengalihan). Diversi berupaya untuk menyelesaikan perkara pidana anak dengan mengupayakan anak (pelaku) menyadari kesalahannya dan bertanggungjawab atas perbuatan salah yang dilakukan tersebut. Diversi bertujuan menyelesaikan perkara pidana anak, dengan memberikan ketenangan bagi korban. Menempatkan anak dalam proses peradilan pidana formal, belum tentu akan memberikan ketenangan bagi korban. Namun dengan mediasi yang mempertemukan pelaku, korban dan perwakilan masyarakat, setidaknya dapat menciptakan kedamaian antara pelaku dan korban. Oleh sebab itu, mediasi penal dapat digunakan sebagai implementasi bentuk diversi dalam penyelesaian perkara pidana anak.

Ketiga, mediasi penal sebagai proses informal, yang dapat digunakan sebagai bentuk diversi. Mediasi penal merupakan suatu proses yang informal, tidak bersifat birokratis, menghindari prosedur hukum yang ketat. Hal tersebut sangat relevan dengan konsep diversi. Konsep diversi menghindari anak agar tidak berhadapan secara langsung dengan proses peradilan yang bersifat birokratis.

Sistem peradilan pidana yang terdiri dari 4 (empat) komponen, kepolisian, kejaksaan, pengadilan dan lembaga pemasyarakatan cenderung bersifat birokratis. Sistem peradilan pidana yang diimplementasikan dalam 4 (empat) sub sistem yakni kekuasaan penyidikan, kekuasaan penuntutan, kekuasaan mengadili/menjatuhkan pidana, dan kekuasaan eksekusi/pelaksanaan pidana, sangat birokratis, prosedural dan ketat. ${ }^{9}$ Diversi menghindari hal ini. Penyelesaian perkara anak (pelaku) sedapat mungkin dihindari dari sifat birokratis, prosedural dan ketat ini, karena akan berdampak pada perkembangan anak. Mediasi penal dapat digunakan sebagai bentuk diversi dalam penyelesaian perkara pidana anak. Keempat, mediasi penal yang memberi kesempatan adanya partisipasi aktif dan otonom para pihak, yang dapat digunakan sebagai bentuk diversi.

Di dalam mediasi penal, para pihak (pelaku dan korban) tidak dilihat sebagai objek dari prosedur hukum pidana. Akan tetapi para pihak, lebih dipandang sebagai subjek yang memiliki tanggung jawab pribadi dan kemampuan untuk berbuat. Mereka diharapkan berbuat atas kehendaknya sendiri. Hal tersebut sangat relevan dengan konsep diversi. Diversi yang berupaya untuk menyelesaikan perkara pidana anak, bermaksud memberi kesempatan bagi para pihak (pelaku, korban dan masyarakat) untuk berkomunikasi dalam

9 Barda Nawawi Arief, Mediasi Penal dalam Penyelesaian Sengketa di Luar Pengadilan, Makalah yang disampaikan dalam Seminar Nasional Pertanggungjawaban Hukum Korporasi dalam Konteks Good Corporate Governance, 27 Maret 2007, Continental Hotel, Jakarta, 2007, hlm. 9. 
menyelesaikan perkaranya. Dalam diversi perkara anak, para pihak yang difasilitasi oleh penegak hukum dipertemukan dengan disaksikan perwakilan masyarakat dan pihak terkait lainnya bertujuan untuk bermusyawarah dan mencapai kata sepakat sehingga menghindari peradilan pidana formal. Sejalan dengan ide dan prinsip kerja mediasi penal, diversi memberi kesempatan adanya partisipasi aktif dan otonom dari para pihak. Oleh sebab itu, mediasi penal dapat digunakan sebagai implementasi bentuk diversi dalam penyelesaian perkara pidana anak. Mediasi penal dapat digunakan sebagai bentuk diversi (pengalihan) perkara pidana anak, semakin ditegaskan dengan menelaah substansi UU Nomor 11 Tahun 2012 Tentang Sistem Peradilan Pidana Anak. Dalam UU ini diversi diupayakan melalui musyawarah. Musyawarah yang dimaksud tentunya tidak jauh berbeda dengan mediasi penal, yakni bermaksud mempertemukan para pihak (pelaku, korban dan masyarakat) guna mencapai kesepakatan. Di beberapa negara, pengaturan mediasi penal, ditempatkan sebagai bagian dari Undang-Undang Peradilan Anak (The Juvenile Justice Act), yaitu di Austria, Jerman, Finlandia, dan Polandia. ${ }^{10}$

\section{Mediasi Penal sebagai Bentuk Diversi Berbasis Keadilan Restoratif}

Dalam penyelesaian perkara berbasis keadilan restoratif, aparat penegak hukum memfasilitasi bertemunya tersangka dan korban serta masyarakat. Pertemuan itu, bertujuan untuk merumuskan skema penyelesaian yang terbaik dan dianggap adil oleh pihak-pihak yang bersengketa Penyelesaian perkara pidana anak (pelaku), menggunakan diversi, maka diselesaikan dengan mempertemukan orang tua/wali anak dan korban serta masyarakat. Pertemuan itu difasilitasi oleh aparat penegak hukum untuk melakukan musyawarah. Musyawarah ini layaknya mediasi penal yang juga mempertemukan pelaku, korban dan masyarakat difasilitasi oleh pihak ketiga (yang tidak terlibat dengan perkara/ netral). Paradigma yang selama ini berkembang dalam peradilan pidana khususnya di Indonesia lebih cenderung pada pemidanaan (retributif). Paradigma tersebut digeser dengan hadirnya restorative justice. Keadilan restoratif memandang bahwa pelaku harus dipulihkan tanpa harus memidana mereka. Keadilan restoratif (restorative justice) merupakan upaya pencarian alternatif pemidanaan (selain penjara). ${ }^{11}$

Pada saat anak (pelaku) melakukan tindak pidana, maka pada saat yang sama dapat merusak keseimbangan tatanan masyarakat. Keseimbangan tatanan masyarakat yang

\footnotetext{
10 Ibid.

11 Ibid., hlm. 169
} 
terganggu haruslah dipulihkan ke keadaan semula (restitutio in integrum) atau kembalikembali ke keadaan semula ${ }^{12}$. Ide keadilan restoratif bermaksud membangun suatu keadaan yang bersifat memulihkan atau menyembuhkan dari keadaan yang sempat terganggu tersebut. Keadilan restoratif menghendaki pemulihan pelaku (anak) dengan korban dan masyarakat sehingga tatanan masyarakat kembali seimbang.

Menurut Muladi, keadilan restoratif, mempunyai beberapa karakteristik. sebagai berikut: ${ }^{13}$

1) Kejahatan dirumuskan sebagai pelanggaran seorang terhadap orang lain dan diakui sebagai konflik;

2) Titik perhatian pada pemecahan masalah pertanggungjawaban dan kewajiban pada masa depan;

3) Sifat normatif dibangun atas dasar dialog dan negosiasi;

4) Restitusi sebagai sarana perbaikan para pihak, rekonsiliasi dan restorasi sebagai tujuan utama;

5) Keadilan dirumuskan sebagai hubungan-hubungan hak, dinilai atas dasar hasil;

6) Sasaran perbaikan pada perbaikan kerugian sosial;

7) Masyarakat merupakan fasilitator di dalam proses restoratif;

8) Peran korban dan pelaku tindak pidana diakui, baik dalam masalah maupun dalam penyelesaian hak-hak dan kebutuhan korban. Pelaku tindak pidana didorong untuk bertanggungjawab;

9) Pertanggungjawaban si pelaku dirumuskan sebagai dampak pemahaman terhadap perbuatan dan untuk membantu memutuskan yang terbaik;

10) Tindak pidana dipahami dalam konteks menyeluruh, moral, sosial dan ekonomis; dan

11) Stigma dapat dihapus melalui tindakan restoratif.

Dari beberapa karakteristik di atas, terlihat jelas bahwa model penyelesaian perkara dengan pendekatan restoratif merupakan penerjemahan dari konsep mediasi penal. Mediasi penal khususnya yang digunakan dalam menyelesaikan perkara pidana anak, dapat dikatakan sebagai penyelesaian perkara menuju pada keadilan restoratif (restorative justice) Berdasarkan inti dalam proses restorative justice yakni membangun partisipasi

12 Sudikno Mertokusumo, Mengenal Hukum Suatu Pengantar, Yogyakarta: Liberty, 1999, hlm. 3.

13 Muladi, Op. cit., hlm. 127-129. 
bersama antara pelaku, korban dan masyarakat menyelesaikan suatu peristiwa atau tindak pidana. Menempatkan pelaku, korban dan masyarakat sebagai “stakeholders" yang bekerja sama dan langsung berusaha menemukan penyelesaian yang dipandang adil bagi semua pihak (win-win solutions) ${ }^{14}$

Dalam penyelesaian perkara pidana anak, menempatkan pelaku (anak), korban dan masyarakat untuk duduk bersama dalam menyelesaikan perkara pidana anak, merupakan suatu hal yang sangat tepat. Mengingat perbuatan nakal yang dilakukan anak, tidak sama dengan kejahatan yang dilakukan oleh penjahat dewasa. Anak tetaplah anak, dengan segala kenakalannya, maka penyelesaian perkara pidana yang melibatkannya, kiranya tepat dengan upaya mediasi penal. Aspek lainnya yang dimaksud seperti aspek moral, sosial, ekonomi, agama dan adat istiadat lokal serta berbagai pertimbangan lain. Utamanya pertimbangan kepentingan terbaik bagi anak (the best interest of the child). Hal ini senada dengan tujuan keadilan dengan pendekatan restoratif. restorative justice merupakan sebuah penanganan tindak pidana, yang tidak hanya dilihat dari kacamata hukum semata. Akan tetapi juga dikaitkan dengan aspek moral, sosial, ekonomi, agama dan adat istiadat lokal serta berbagai pertimbangan lain ${ }^{15}$. Penyelesaian perkara pidana anak dengan mediasi penal sangat berperan penting guna mencapai keadilan restoratif, yang tidak hanya memandang sisi hukum saja, namun mempertimbangkan aspek lainnya.

\section{KESIMPULAN}

Mediasi penal sebagai bentuk diversi (pengalihan) dalam penyelesaian perkara pidana anak di Indonesia, dapat terlihat dari ide dan prinsip kerja mediasi penal, yang sangat sesuai dengan tujuan diversi (pengalihan) perkara anak dari proses peradilan pidana. Mediasi penal sebagai bentuk penyelesaian perkara pidana anak, sejalan dengan pendekatan menggunakan keadilan restoratif. Restorative justice yang berupaya menggeser paradigma selama ini bahwa penyelesaian perkara pidana harus dengan pemidanaan, sesuai dengan ide dan prinsip kerja mediasi penal yang lebih mengutamakan musyawarah. Proses penyelesaian sengketa dengan cara mediasi, baik yang dilaksanakan di dalam sistem peradilan pidana maupun di luar pengadilan, yaitu adanya kesepakatan atau perjanjian perdamaian yang sama-sama memiliki nilai pembuktian dan mengikat bagi para pihak.

\footnotetext{
14 Bagir Manan, Restorative Justice (Suatu Perkenalan) Refleksi Dinamika Hukum Rangkaian Pemikiran dalam Dekade Terakhir, Jakarta: Perum Percetakan Negara RI, 2008, hlm. 4.

15 Jeff Christian, Juvenile Justice (Keadilan yang Memulihkan bagi Anak). Makalah Lokakarya Konsultatif Restorative Justice. Jakarta: Kerjasama KPAI-Pemerintah Swedia, 2009, hlm. 1.
} 
Namun, keduanya belum memiliki kekuatan hukum yang pasti sebagaimana layaknya putusan pengadilan yang berkekuatan hukum tetap. Kesepakatan perdamaian hasil dari mediasi di dalam pengadilan dapat langsung ditingkatkan statusnya menjadi akta perdamaian melalui majelis hakim pemeriksa perkara pada saat persidangan dan diputus menjadi putusan pengadilan. Sedangkan, perjanjian atau kesepakatan perdamaian hasil mediasi di luar pengadilan, baru memperoleh kedudukan sebagai akta perdamaian setelah para pihak dengan bantuan mediator mengajukan gugatan perdamaian melalui Pengadilan Negeri, vide. Pasal 36 PERMA Nomor 1 Tahun 2016. Sehingga, akta perdamaian dimaksud memiliki kepastian hukum dan berkekuatan hukum tetap (incracht van gewijsde).

\section{Daftar Pustaka}

\section{Buku}

Achmad, Yulianto, Mukti Fajar. Dualisme Penelitian Hukum Normatif \& Empiris, Yogyakarta: Pustaka Pelajar, 2010.

Christian, Jeff, Juvenile Justice (Keadilan yang Memulihkan bagi Anak). Makalah Lokakarya Konsultatif Restorative Justice. Jakarta: Kerjasama KPAI-Pemerintah Swedia, 2009. Manan, Bagir, Restorative Justice (Suatu Perkenalan) Refleksi Dinamika Hukum Rangkaian Pemikiran dalam Dekade Terakhir, Jakarta: Perum Percetakan Negara RI, 2008. Marzuki, Peter Mahmud, Penelitian Hukum, Jakarta: Kencana, 2005.

Mertokusumo, Sudikno, Mengenal Hukum Suatu Pengantar, Yogyakarta: Liberty, 1999. Muladi, Hak Asasi Manusia, Politik dan Sistem Peradilan Pidana, Semarang: Badan Penerbit Universitas Diponegoro, 1997.

\section{Jurnal dan Makalah}

Arief, Barda Nawawi, Mediasi Penal dalam Penyelesaian Sengketa di Luar Pengadilan, Makalah yang disampaikan dalam Seminar Nasional Pertanggungjawaban Hukum Korporasi dalam Konteks Good Corporate Governance, 27 Maret 2007, Continental Hotel, Jakarta, 2007.

Lasmadi, Sahuri, "Mediasi Penal dalam Sistem Peradilan Pidana Indonesia", Jurnal Ilmu Hukum Inovatif, Vol. 4 No. 5, 2011.

Rozah, Umi, “Membangun Konstruksi Politik Hukum Medias Penal Sebagai Alternatif Penyelesaian Perkara Pidana", Jurnal Masalah-masalah Hukum, Vol. 39, No. 3, 2010. 